Journal of Business, 01(02), 01-11

Vol. 01, No. 02: March 2016)

Journal of Business

Open access available at http://journalofbusiness.us

\title{
Productive Matrix Change in Ecuador and the Petroleum Crisis. Case Study: Entrepreneurs and Productive Associations
}

\author{
Jhonny Villafuerte $\mathrm{a}^{*}$, Eder Intriago ${ }^{\mathrm{b}}$ \\ a Faculty of Education, University Laica Eloy Alfaro de Manabí, Ecuador, Email: jhonny.villafuerte@uleam.edu.ec \\ b Faculty of Education, University Laica Eloy Alfaro de Manabí, Ecuador, Email: eder.intriago@uleam.edu.ec \\ *Corresponding author's email address: jhonny.villafuerte@uleam.edu.ec
}

\section{A R T I C L E I N F O}

Received: 01-02-2016

Accepted: 11-03-2016

Available online: 14-03-2016

Keywords:

Economy crisis,

leadership strengthen,

productive systems,

ICT usage,

Entrepreneurs.

JEL Classification:

A14, H61, J15, J68

011

\begin{abstract}
A B S T R A C T
The worldwide oil prices reduction from USD 109,45 in 2012 to USD 26,5 in 2016 (OPEC, 2016) threatens economic crisis in those countries, whose economies are still directly dependent on the exploitation and exportation of oil, as is the case of Ecuador in South America. This paper aims to describe the public politics set as contingency measures in the social economy sector, taken to adjust to the economic impact that can be foreseen. In this document, we refer to the 2013-2017's objectives of the Ecuadorian development national plan: 8, 9, 10 and $11^{\text {th }}$, and present an analysis of interviews applied to entrepreneurs and community association leaders, in connection with the national productive matrix change implications. This study describes also, the productive settings that urban entrepreneurs and farmers' associations implement in 2 geographical zones (Manabí and Esmeraldas) on the Ecuadorian coast, which has agricultural, tourist and fishing potentialities.
\end{abstract}

The results of this work, ratify that "productive associations" set of strategies for the social capital development in an organized group (Moran, 2010) and the theories of economy development of Basu, (2000) and Moon, (2014). We also consider that the productive matrix change process in Ecuador requests of urgently relevant adjustment in the producers' profiles such as: the strengthening of ICT usage, and the addition of the sustainability vision in their new productive projects.

(C) 2016 The Authors. This is an open access article under the terms of the Creative Commons Attribution License 4.0, which allows use, distribution and reproduction in any medium, provided the original work is properly cited.

DOI: http://dx.doi.org/10.18533/job.v1i2.18

\subsection{Introduction}

In Ecuador, there is a high expectation in that "rural producers' associations" and "urban entrepreneurship initiatives" do contribute to minimizing the economic impact that worldwide oil price reduction (from USD 105.00 in 2012 to USD 20.00 in 2016) generates as the result of this oil dependence economy system.

In 2008 the new Constitution of Ecuador (Republica del Ecuador, 2008) implemented a public politic framework in order to diversify its sources of income and to eliminate the oil exploration and exportation dependence. The most important national objectives were: the "change of the Ecuadorian productive matrix", the "introduction of the law for the popular and solidarity economy" and the "investment in education" in order to develop its competence capacity level. 
In the 2012 Millennium Development Goals (MDG) report, it was shown a remarkable progress made by countries, but those MDGs are still achievable; and in order to reach those goals, it is still considered necessary the support from the local-national governments, the international community, the private sector and civil society (United Nations, 2012). In Latin American Countries (LAC), a low gear remained in the first half of 2013, there was a large decrease in activity in Mexico, Brazil and Peru. In Ecuador, the population is waiting for an economic-political package that the government may implement in order to face the oil price crisis, which could include increasing the added value tax (IVA) and the lowering of the deposit reserves.

This research is presented as context a chronological review about the most important facts that affected the Ecuadorian economy during the 1970 - 2015 period. After that, we present a review of related literature published about: theories of dependence and development, the model and leadership associations, and the human capital. Among the most relevant authors considered in this work are: Moon (2014), and Basu, (2000) who discuss to theories of development. The results of the research are presented in a strategic format as a route of work that we propose be applied by the rural associations for their competitiveness strengthening. They concentrate in the fields: matrix of organization weaknesses and strengths, motivations of entrepreneurs, business conditions and ICT usage for marketing.

Our motivation is to contribute to the discussion on the dependence of Ecuador`s economy on oil exportation, to determine the rural associations' current state of maturity in Ecuador, and to help the rural associations to advance in their "national productive matrix change" process. This research answers the questions: What are the new competences that leaders require to manage efficiently their rural associations and entrepreneurs? What are the ICT contents to be added to the training plan for entrepreneurs? How to consider the commerce abilities.

\subsection{Problem and Context}

After 200 years of colonization in Latin America, Ecuador emerged as a new nation with relevant social inequities characterized by an economy system based on the production of commodities for the tribute to the Spanish Royalty. Years after, a republican system of government was stablished, but the limited access to technology became a way of dependence that persists today.

In this young nation, the oil explorations arrived during the 70s with the promise of richness and a better future for its population. A military dictatorship government took place in order to keep the control and security in this country. During the 80s a plebiscite got the democracy back to Ecuador and a military conflict between Ecuador and Peru took place for territorial reasons. This historic conflict brought death to both countries and the increase of their international debts, in name of the sovereignty.

This weak democracy nation faced the growth of corruption, and power abuses from the new highest government positions against public workers, who became rich by the exploration and exportation of oil, bringing about a deep poverty to the civilians, whose competitive abilities were not strengthened during decades.

The impact of the El Niño Phenomenon destroyed the highway system, and generated losses from the export of coffee, bananas and cocoa cost USD 640 million (5\% of gross domestic product - GDP). In January 1983, 1.200 billion dollars of payments on foreign debt that had become due were renegotiated between November 1982 and December 1983 (25\% of the Ecuadorian external public debt). For that reason, a strong economic repression generated the appearing of a revolutionary guerrilla group self-named Movement Alfaro Vive Carajo! which was declined in the 90s. That international debt was also the cause of neoliberal policies imposition in Ecuador during the 90s and the El Niño phenomenon which caused destruction of the agricultural production sector and public schools, roads, etc., in 1997-1998.

The government gave loans close to 200 billion sucres (currency in Ecuador until 1999) for the development of medium and large national industry through the National Finance Corporation (CFN). The international commerce limited to the oil exportation, began to introduce the diversity of income by exporting agricultural commodities such as coffee, cocoa and bananas, and later exports of shrimp and exotic flowers but, this industry development was not enough and very soon, high inflation rates limited even more the productive development by making income production and industrial progressive technologies unachievable in coherence with the negative impact of the theory of the "endogenous growth" in which the slow model of development, reduce the investments in human capital (education), infrastructure, or research and development (World bank, 2000).

The hegemonic imposition of economic packages generated unemployment and mass protests came to overthrow governments. The high rates of inflation, which rose from a rate of 2,500 to 25,000 sucres per dollar 
of United States put in crisis the national financial system. This led to a feriado bancario (No Banking Activity for a week) in 1999. This economic phenomenon caused the bankruptcy of financial companies and limited further national development. This economic crisis was the reason for 1 million Ecuadorians migration to Spain and Italy especially, during 1995 and 2010. From the year 2000 until 2010, the Ecuadorian migrants in Europe sent money to their families in Ecuador. These transactions ranked as the third for source for external income, which was declining in subsequent to the "family re-union law" implemented in Europe from 2008 which allowed the entry of relatives of migrants to Europe.

"... Pan, techo y empleo - food, houses and employment ... La fuerza de los pobres - the strength of the poor people ... hasta la victoria siempre - forever victorious" more than, presidency election slogans, they represent economic models stablished in Ecuador where, in order to obtain the maximum income growth, the "environmental considerations were left to languish on the sidelines; the standard of living was often allowed to slide; large inequalities between classes, regions, and genders were ignored; and poverty was tolerated more than it should have been" (Basu 2000, p. 64) but, after almost 10 years of oil international high price, such conditions changed as it is presented in the following board and graphic.

\begin{tabular}{|c|c|}
\hline \multicolumn{2}{|c|}{$\begin{array}{c}\text { Table 1: Table No.1. Crude oil international Price } \\
\text { Period 2006/2016 }\end{array}$} \\
\hline Year & Price \\
\hline 2016 & 26,5 \\
\hline 2015 & 49,54 \\
\hline 2014 & 96,29 \\
\hline 2013 & 105,87 \\
\hline 2012 & 109,45 \\
\hline 2011 & 107,46 \\
\hline 2010 & 77,38 \\
\hline 2009 & 60,86 \\
\hline 2008 & 94,1 \\
\hline 2007 & 69,04 \\
\hline 2006 & 61 \\
\hline
\end{tabular}

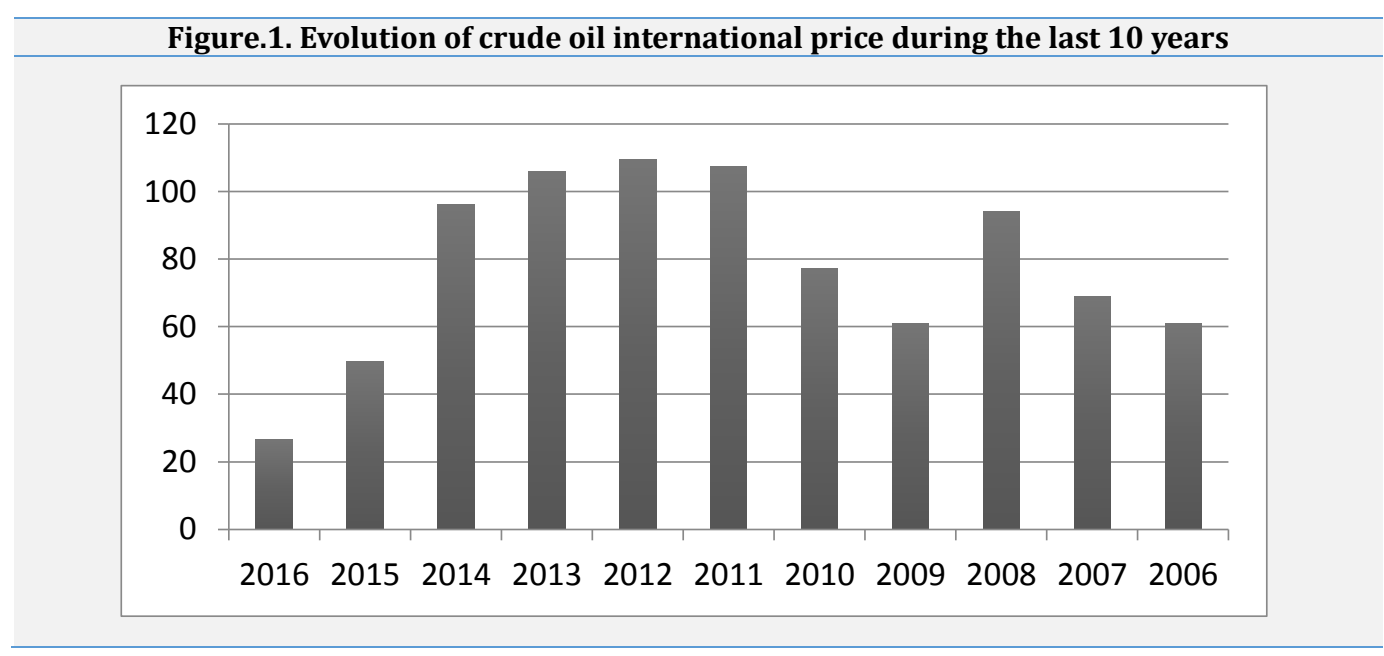

Source: http://www.statista.com/statistics/262858/change-in-opec-crude-oil-prices-since-1960/

Part of the crude oil high price until 2014 was used for the reconstruction of the modern national highway system, to improve productive initiative and the fostering of the transformation and exportation of agriculture products, the improvement of access to internet, public education and health service. So, Ecuador went from $3.500 \mathrm{~km}$. to $46.000 \mathrm{~km}$., of optical fiber Internet connectivity, reducing the digital access gap from 32\% in 2013 to 14\% in June of 2015 (Republica del Ecuador, 2015). 
The investment in education increased from 2.5\% of GDP in 2006 to 5.5\% at the end of 2011 (Republica del Ecuador, 2013). The public basic education was integrated to health, nutrition and production. Training of officials and teachers took place as a national literacy campaign and a control of the quality of higher education was implemented, financing international training programs for talented professional and professors. According to Rocio Blanco (2013), the Ecuadorian Ministry Education has as a goal to offer the population quality education in order to deal with the differences in the community, in order to reach better levels of competitiveness.

The national development plan for 2009-2013 (Republica del Ecuador, 2009) promoted the reconstruction and development in this country plus, the usage of US dollars as currency in Ecuador, created a new "American dream version" in South America, where Peruvians, Colombians, Venezuelans and Bolivians came to Ecuador looking for a place of work and live.

The following are the "new productive matrix" goals that we consider as the most relevant for the productive development in Ecuador: "8) to consolidate a social and solidary economic system, sustainably. 9) Ensure decent work in all its forms, and 10) to promote the transformation of the productive matrix" (Republica del Ecuador, 2009). But, the reduction of oil prices worldwide put these developing country`s projects, which had begun the process of the reduction of the oil market dependence, at risk.

The project is of fundamental importance in developing global economies where innovation is a specific function of entrepreneurship, whether in an existing business, a public service institution, or the beginning of a new adventure of one individual (Drucker, 1985). Changes in the global oil market put at checkmate small entrepreneurs in Ecuador which activates them in their capacities innovative, flexible, dynamic, able to take risks, creative and growth-oriented. Entrepreneurs are faced with a new scenario drawn by the technological development, the establishment of global trade flows, and demands for the installation of initiatives resulting in a new competitive landscape characterized by higher degrees of uncertainty, ambiguity and risk. Which is due to become increasingly complex to get to know the needs of potential customers and users, and manage risk aspects mutate making the business outlook fragile. The access to agriculture products market, the use of ICT in the business new conditions, and the entrepreneur motivations are some of the fields that the new profile requires in order to become more competent. From the observation of an increased competitive rate and speed of change in the economic outlook, it has been argued that the need for even large businesses and corporations to become more enterprising and persevering needs to increase (Perace and Robinson, 2005)

\subsection{International Dependence Models and Sustainability}

The growth of international capitalism and multinational corporations caused poor countries to be further exploited and more dependent on developed countries during the end of the century XX. Poor and developing countries as is the case of Ecuador, therefore could not expect sustained growth from that dependence in a product as oil that impacts also over the environment. As Basu (2000) commented "the standard of living was often allowed to slide [...] and poverty was tolerated more than it should have been" (Basu, 2000, p. 64)

In 1990 the "Endogenous growth or the new growth" theory emerged to explain the poor performance of many less developed countries. That slow model considered technological change as an exogenous factor but, that process has not been equal for every country and nor has it been exogenously transmitted in most developing countries (World Bank, 2000).

According to Ferraro (2008) about the international economy dependence theory, developing countries should end it by breaking up their relationships with the developed countries, but it raises the question: how can poor countries finish their commercial relationships with the rich countries when, they are the source of the limited income? It refers to a change of the economy structural model that includes the increase of support and dynamic cooperation among the other developing countries (autarky policy). Those countries that often experienced stagnant growth, but decided to re-open their economies to rich countries, as in the case of China, India and Tanzania (Ferraro, 2008; Todaro \& Smith, 2009). In other words, the success results of industrialized economies such as Taiwan, Hong Kong, South Korea and Singapore are the result of the policy of emphasizing trade between poor countries with advanced industrial countries that was applied during the 1970s - 1980s (Ferraro, 2008) but such goal, induced nations to focus on the rapid growth of national incomes leaving as pending the environmental management (Todaro \& Smith, 2003). According to Kates et al. (2008) the debate about the condition of development and sustainable countries seeks to answer the following two questions: "What should be sustained" and "What should be developed"? 
Thampapillai (2002) affirms that, environmental economists concerned in the long-term neglect the environmental assets is not warranty of the durability of the economic growth. In contrast, Meier (2000) argued that international dependence model is not the result of the predatory activities of the developed countries and the international agencies, in fact, its origin is in the same heavy state intervention and different forms of corruption presented in the developing countries. He added that new growth models therefore promote the role of government and public policies in complementary investments in human capital formation, and the encouragement of foreign private investments in knowledge-intensive industries, such as computer software and telecommunications. The elements of the sustainable development aims are economic prosperity, social equity and environmental protection which improve the quality of life in a comprehensive manner. This allows the integration of economic, social, environmental and cultural aspects which replace the market work for the economy or capitalism interests (Skousen 2007).

Those elements must be integrated in a harmonious manner to enhance the intergenerational "well-being" (World Bank, 2002). The modern nations measure their standard of living and quality of life focusing on the quantitative and qualitative aspects: health, education, environment and material well-being (Berenger \& Verdier-Chouchane, 2007). Also, "a country's resource endowment and size, its government's policies and objectives, the availability of external capital and technology, and the international trade environment" (Todaro \& Smith, 2009, p. 120).

The financial crisis had a stark but varied effect on Latin American countries. The economies of major oil exporters like Venezuela and Mexico were buffered as prices rose through the early part of 2008. The oil price slump during the second half of the year had the reverse effect. Brazil, Argentina, and Ecuador were beset, to a lesser degree, with similar problems. Venezuela was forced to reduce its regional spending, which had been made possible in large part through commodity exports. Meanwhile, equity prices fell across Latin America as hedge funds and other institutional investors cashed out of investments in emerging markets. The region's economies were dampened more generally by declining import demand from the world's leading economies, including the United States. Some Latin American countries, perhaps most notably Argentina, also faced severe inflation problems and saw their sovereign debt ratings lowered by ratings agencies. But fiscal reform in some countries--Brazil, Colombia, Peru, and Chile--put them in far better shape to weather the crisis than they were during the emerging markets crisis of the late 1990s. On the international stage, Latin American policy priorities were scattered as of early 2009. Ahead of the April 2009 G-20 summit, the three Latin American countries that attended spoke out on different policy points. Argentina urged a relaxation of some IMF rules. Mexico pushed for trade openness, particularly given simmering trade disputes with the United States. Brazil, experts say, sought to establish its position as a leading voice for the developing world.

\subsection{The entrepreneur and the rural association}

The terms entrepreneur and entrepreneurship are newly used in the Spanish, arising from the translation of words Entrepreneur and Entrepreneurship (Filion, 2011). For Drucker, (1985) entrepreneur is a person who demonstrates competence to visualize, define and achieve objectives. The entrepreneur must include at least six elements (Filion, 2011), those are: 1) innovation 2) recognizing of opportunities, 3) moderately risky decisions taker, 4) leading to shares, 5) efficient usage of resources and 6) capability to add value to the products and services.

Drucker (1985, p.150) suggested that an entrepreneurship should be analyzed by the type of activity that he or she performs. Some of those activities should be defined as innovation, and they are also, indirectly observed by the industries (Ireland, Reutzel and Webb 2005; Vanderwerf and Brush 1989). Also, Vanderwerf and Brush (1989) noted the world "community" in the industry context is commonly used as a reflection of a work made by a group of people. They noted the importance of the study of high-tech firms because, they generate impacts on innovations. However, it is undeniable that elements such as commitment established through the application of (OCQ) - Organizational Commitment Questionnaire (Porter and Smith, 1970), and the entrepreneur education level, were considered as individual variables but, these can affect to the enterprises performance.

Psychologists and economists such as Chell, Haworth, and Brearley (1991) think of entrepreneurs as those individuals who are alert to business opportunities. They are being proactive rather than reactive. They are always seeking for opportunities to generate innovations, they are people of high imagination, people with ideas of improvement. They are agents of change with capabilities to face difficult challenges. They are people who take adventures and risks, manage him/herself to adapt strategies and financing for their ideas. An entrepreneur is able to generate their own employment. It has been assumed that they are individuals who possess a high level of internal locus of control and capable of taking their own destiny. 
The personality of an entrepreneur has features like high need for achievement, self-confidence, humor (internal locus of control), risk takers and personal values. Beugelsdijk and Noorderhaven (2005) affirm that entrepreneurs are more individually oriented than the rest of the population. Blanchflower and Oswaldo (1990) and Blanchflower and Meyer (1994) argue that the vision of the entrepreneur is one of the factors influencing the probability of detecting the opportunity of a business. Blanchflower and Oswaldo also suggest that entrepreners are ready to achieve their self-employment. They were hostile as a child with others, but they do not attack, but are anxious.

The internal locus of control (MOOD) was also occasionally tested as a determining element of achieving selfemployment (self-employed) in consequence, they are capable of taking charge of their own future. This is commonly associated with motivation or action which promotes entrepreneurial self-employment. McClelland (1965) in their initial research about the personality as a self-employment determined that entrepreneurs are characterized by the desire to work and a high need for achievement.

ICT "offers the opportunity to create flexible environments for learning, helping to eliminate the time and space limitations. [...] Learners can develop abilities and acquire new competences" (Cabero, 2005b, p.80-81). "ICT supports people to work in cooperative way sharing information and interacting" (Cabero \& Barroso, 2016, p. 32)._The term "leadership" refers to "the capacity and ability of a person to lead a group, and influence the behavior and motivation of members to participate in an orderly and voluntarily way, expecting to achieve the goals and objectives that have been proposed". The "Association" is considered by Rosales (1997) as a strategy that promotes productive competitiveness. This is the summation of interdependent individuals without the condition to solve their own problems by themselves but who have the desire to collaborate and help each other. The Association promotes participatory work where each member has willingly decided their integration; and together they seek to achieve short-term objectives of common interest such as: acquisition of raw materials, access to credit, research and technology development. The resources of rural communities that have enough suitable land and water are enhanced through community association supported by networks within and outside the community.

Producer associations enhance growth initiatives business focus and more stable relationships generated in time (Valdez, 2007); and their own social dynamic power capabilities of innovation and technology development, to access alternative sources of financing and reducing production costs. Meanwhile, Colmenarez and Delgado, (2003) define the partnership as a strategy that enhances the capabilities of an organized group; and it becomes a requirement for survival of the majority of farmers' ventures. They are social spaces where relationships of trust, reciprocity and cooperation emerge; and which constitute intrinsic motivations that keep the dynamics of human groups (Morán, 2010). The Food and Agriculture Organization (FAO) in its categorization of popular organizations, defines "associations" as the local, community, rural and grassroots organizations; as formal or informal, voluntary, democratic, social groups focused on the idea of development from the bottom up. This participatory mechanism is used for obtaining credit, inputs, training and other services promoting the welfare of its members.

Colmenarez and Delgado, (2003); Valdez, (2007); and Morán, (2010) claim that associations are a tool that contributes to participatory management of sustainable socio-economic initiatives; and spaces are dynamics that requires all its dimensions serve for identifying and better understanding of their role as agents of social development.

Farmers' associations gain momentum in Latin America since the 90s, becoming models of integration and participation in the rural area; whose first benefit was working to enhance access to basic services such as education, health; and then access to financial services and credit, production technology and machinery, and agricultural input packages. In 2000, Ecuadorian producers who wanted to be benefited from development projects had to be members of an organization or to be part of a legally constituted association; thus, they could have access to productive credit and for the development of non-traditional production clusters and access to associative markets. In 2010, participation and democracy were essential for the decision-making in the government associative components. However, other studies presented at the FLACSO Congress 2015 in Quito revealed that the highest priority of farmers' organizations were focused on the economic aspects, while their social objectives were relegated to a second position and cultural issues were presented, but in minority.

Meanwhile Dini (1996) refers to a process called "integration" through which people join forces and capabilities to achieve competitive advantages. Colmenarez and Delgado, (2003), consider that associating is a collective strategy that enhances the performance of activities that are required for the survival of rural enterprises; meanwhile, Valdez, (2007) indicates that the common objectives pursued by associations are related to the 
acquisition of raw materials, generating a more stable relationship in time with activities such as research in innovative production processes, the development of technologies to help reduce production costs, and incrementing the access to sources of formal and favorable financing.

Currently, the partnership model is threatened by the lack of cooperation between partners; and above all, lack of confidence in their leaders, and generated effect is that the members of the association do not want to assume the role of leaders because being the leader of the producers is time consuming, and it exposes their personal image to the community; plus, they have to assume transportation costs, etc.

\subsection{Human Capital}

Economists included in the human capital, the categories education, self-employment experience, experience in work with decent wages, and age. The model of Lucas (1988) for human capital promotes the ability to manage and measure the growth of the trend to self-employment. A high level of education could facilitate the entry of large wage sectors rather than generating their own work but, studies of Evans and Leighton, (1989) and Bates (1990) agree with the hypothesis that, those having a high-level of education care more about their own firms than, those with low education level.

Very low and very high levels of education have a strong relationship with entrepreneurial activities. Another feature is the experience as positive relationships between self-employment and work experience that has been demonstrated by Schiller and Crewson (1997) who, argued that the work experience is positively related to positive outcomes for men and self-employment but, it has been negative for women. Meanwhile, Evans and Leighton (1989) found that the probability of self-employment income is independent of the age or experience during the first 20 years of employment. About the education in adults, Bosio affirms that, they expect every new learning have immediately application to the real life, and for that reason, it is necessary to warranty that function in every activity of learning; otherwise, adults will not acquire new competences. (Bosio, 2011, Pp. 41-42). Moran (2010) in the regarding of the competitiveness explains that, they are strategies to develop the capital stock from a group. This is represented in relations of trust, reciprocity and cooperation; and Putnam (1993)) quoted in MIDEPLAN (2003) defines the term "social capital" as those "aspects of social organizations such as networks, norms and trust that facilitate action and cooperation for mutual benefit" (p. 22).

The IICA Inter-American Institute for Cooperation on Agriculture (2006) indicates that the competitiveness of the agricultural production system depends largely on the ability of farmers to produce for the relationship and partnership between the actors. As a strategy, this allows producers and entrepreneurs to accept and adapt to economic and market changes that occur permanently in society. In the case of Ecuador, there is the Law of Popular Economy and Solidarity (Republica del Ecuador, 2012), which proposes an alternative development, enhancing the access of vulnerable groups to the formal financial system, and related services in the country. At the same time, the change of production model raises challenges of competitiveness, efficiency and innovation such as access to special niche markets, financial sustainability, and addition of value to traditional products; in such process the use of ICT, management principles, motivation strategies and sustainability vision make possible to improve entrepreneurs and farmers competitiveness capabilities.

To reach prosperity, countries need skilled and educated workers. The challenges of poverty eradication, dealing with climate changes and achieving truly sustainable development in the coming decades instruct us to act together. With collaboration, leadership and investment in education, we can transform the lives of people, the economies of our countries and the world at large (Moon)

\subsection{Methodology}

Using the qualitative method of research, 6 agriculture associations were studied during the period 2014-2015. They involved 180 men and 70 women producers in ages between 30 and 55 years. Three of these rural associations are located in Manabí (Montubio [countryside] population) and the other three entrepreneurs' organizations are located in Esmeraldas (Afro-Ecuadorian population) by the cooperation of PUCESE University.

The techniques applied were focal groups and deep interviews, in order to obtain information about their weakness and strengths competitiveness factors. ( 2 focal groups in each association). The categories studied are: 


\begin{tabular}{|c|c|}
\hline \multicolumn{2}{|c|}{ Table 2: Matrix of organization weakness and strengthen } \\
\hline Categories & Sub categories \\
\hline Commerce & Marketing and commercialization \\
\hline \multirow[t]{4}{*}{ Human resource management } & Leadership \\
\hline & Adaptation to the legal change, normative framework \\
\hline & Leadership and gender equality \\
\hline & Intergenerational and intercultural participation \\
\hline \multirow{4}{*}{$\begin{array}{l}\text { Production: food safety and } \\
\text { Transformation }\end{array}$} & Capacity for processing raw materials and challenges around productivity \\
\hline & Services supply \\
\hline & Agricultural production systems \\
\hline & Agricultural production systems \\
\hline Access to financial system & $\begin{array}{l}\text { Autonomy for financial management } \\
\text { Access to the financial system, credit }\end{array}$ \\
\hline
\end{tabular}

\section{$5.0 \quad$ Results}

The data obtained in the interviews was processed according to the following subcategories

Table 3: The new peasant profile for the productive matrix change in Ecuador

\begin{tabular}{|c|c|}
\hline Sub Categories & Action Plan \\
\hline $\begin{array}{l}\text { Marketing access and Capacity for } \\
\text { processing raw materials }\end{array}$ & $\begin{array}{l}\text { Training for effective sales, record sales, billing, etc. } \\
\text { Access to special markets. } \\
\text { Open to productive technology changes. } \\
\text { Use of ICT for market access. } \\
\text { Capability for addition of value to agricultural products. }\end{array}$ \\
\hline Leadership and gender equality & $\begin{array}{l}\text { Participation in democracy } \\
\text { Opportunities access with gender equity. } \\
\text { Presentation of financial reports to the association member } \\
\text { Participation of every partners without any kind of discrimi } \\
\text { Communication and easy accessibility of every member to t }\end{array}$ \\
\hline $\begin{array}{l}\text { Adapting to the laws and } \\
\text { regulatory change }\end{array}$ & $\begin{array}{l}\text { Knowledge of the new laws related to the production activit } \\
\text { Capability to apply the laws and new procedures and regula } \\
\text { Use of ICT for the access to regular information and apply th }\end{array}$ \\
\hline Vision of sustainability & $\begin{array}{l}\text { Openness to sustainable technologies. } \\
\text { Compromise to the rational use of natural resources. } \\
\text { Capability for the production certification. }\end{array}$ \\
\hline $\begin{array}{l}\text { Management and support of ICT } \\
\text { applications }\end{array}$ & $\begin{array}{l}\text { Administration with technical capability. } \\
\text { Administrative structure. } \\
\text { Take of decision based on administrative principles. }\end{array}$ \\
\hline $\begin{array}{l}\text { Access to the national financial } \\
\text { system, credit. }\end{array}$ & $\begin{array}{l}\text { Openness to the financial advising services } \\
\text { To improve understanding of accounting information }\end{array}$ \\
\hline & $\begin{array}{l}\text { Tax payments capability. } \\
\text { Knowledge of the banking services and procedures on li }\end{array}$ \\
\hline
\end{tabular}

\subsection{Entrepreneur's motivations}

Regarding the motivations of entrepreneurs, $96 \%$ of surveyed participants, rated as very important the desire to "improve their income". This was the most frequent reason for motivation followed by $93 \%$ of the "desire of independence", the "desire for self-realization" 92\%, "contribution to the development of my community" $90 \%$ and "capability to perceived opportunity of business" with $88 \%$ of entrepreneur's surveyed main motivations. 


\begin{tabular}{|c|c|c|c|c|}
\hline & & & & \\
\hline CATHEGORIES & MANABI & ESMERALDAS & TOTAL & $\%$ \\
\hline Improvement of income level & 143 & 145 & 288 & 96 \\
\hline Desire of independence & 137 & 142 & 279 & 93 \\
\hline Desire of self-realization & 134 & 142 & 276 & 92 \\
\hline $\begin{array}{l}\text { Contribution to the development of my } \\
\text { community }\end{array}$ & 135 & 135 & 270 & 90 \\
\hline capability to perceived opportunity of business & 131 & 133 & 264 & 88 \\
\hline
\end{tabular}

\subsection{Route for the competitiveness capabilities development.}

As a result of this work, we present the following route that entrepreneurs and farmers' associations leaders can apply, as a way for the change of productive matrix in Ecuador.

Table 5: Competitiveness capabilities for productive matrix change

Entrepreneurs in Esmeraldas
The use of ICT enhances access to information
concerning the processing of products in
internet.
Permanent recording of information, cycles of
production, suppliers and clients contacts
database, etc. using ICT.

Open mind to the introduction of productive sustainable technologies.

Compromise in the application for long periods of sustainable technologies in their harvests.

Sensitize partners about the need for generational change according to technological advances.

The concrete opportunity for the association to integrate young people who already have knowledge of ICT.

$\begin{array}{lr}\begin{array}{lr}\text { Sub categories } \\ \text { Capability }\end{array} & \text { for } \\ \text { processing } & \\ \text { agricultural } & \text { raw } \\ \text { materials } & \text { and } \\ \text { challenges } & \text { around } \\ \text { productivity. } & \end{array}$

\section{Agricultural}

production systems and openness to new technologies

The point of view of their members towards sustainability Agriculture associations condition

for Promote entrepreneurship and proactive partnership attitude in their communities. Use of ICT for checking and buying and productive supplies.

Control of the production expenses applying indicators in electronic spreadsheets

Sensitize producers to develop the vision in the long term.

Access to public services on line.

\subsection{Conclusions}

This study reached the aim: to identify the weakness capabilities in the Manabí and Esmeraldas entrepreneurs and farmers' associations leaders. The results of this research show that the "wish for independence (96\%), and self-realization (93\%)" are the most important motivations for their process of competitiveness capabilities strengthen, which considers: Capability for processing agricultural raw materials and challenges around productivity; Agricultural production systems and openness to new technologies; The point of view of their members towards sustainability; Intergenerational and intercultural participation.

We consider, the change of national production matrix in Ecuador is an adequate public policy, utilized as a strategy for the reduction of the crude oil economy dependence of Ecuador (National Plan of development or Plan of well living 2013-2017). However, we observe that the investment in the strengthening of the producers' competences should be kept even, the possible recession regulations that the current government of Ecuador may implement; because, the competitiveness development is a fact in the long term.

Crude oil has had a high price for almost 10 years and during that period Ecuador had the opportunity to finance the process of modernization of the state and to offer good living conditions to its population. The highway national system was rebuilt, education and health services were priorities in the development public politics, hundreds of migrant families returned to Ecuador but, the competitiveness of the country had a slow growth in comparison to other countries in the region. Since 2006 until current days the price of crude oil fell from USD 
105,00 t USD 20,00 and there are no signs of change; situation that has an impact over the state economy structure.

Because, Ecuador has important natural resources to protect in order to develop agriculture and tourism as sustainable industries; we agree with Basu (2000) when, he affirms that in order to maximize the income growth, a nation should not leave the environmental considerations.

At the end of this work, we ratify Moon's (2014) position about "prosperity" when he affirms that "countries need skilled and educated workers, [...] the truly sustainable development instructs us to act together" (p. 1) and we invite other researcher to deepen their works in this topic: Reduction of the developing countries economic dependence in the crude oil exportation.

\section{References}

Basu, K. (2000). On the goals of development. In G. M. Meier \& J. E. Stiglitz (Eds.), Frontiers of development economics: The future in perspective, Pp. 61-86. Washington. World Bank and Oxford University Press.

Bates, R.H. (1990). Capital, Kinship and conflict: The structuring in Kinship Societies. Canadian Journal of African studies 2 .

Berenger, V., \& Verdier-Chouchane, A. (2007). Multidimensional measures of well-being: Standard of living and quality of life across countries. World Development, 35(7), Pp.1259-1276.

Blanco, R. (2013). Escuelas inclusivas del Ministerio de Educación del Ecuador. OREALC/UNESCO. Consultado en http://educacion.gob.ec/escuelas-inclusivas/

Blanchflower, D. G., \& Meyer, B. D. (1994). A longitudinal analysis of the young self-employed in Australia and the United States. Small Business Economics, 6(1), Pp.1-19.

Blanchflower, D., \& Oswald, A. (1990). What makes a young entrepreneur? (No. 373).

Beugelsdijk, S., \& Noorderhaven, N. (2005). Personality characteristics of self-employed; an empirical study. Small Business Economics, 24(2), 159-167.

Bosio, V. (2011). La educación de adultos: Un acercamiento a los principios básicos del aprendizaje de adultos del idioma inglés como lengua extranjera, Pp.41-42, recuperado en http://bibliotecadigital.uda.edu.ar/objetos_digitales/271/seminario-4009-la.pdf

Cabero, J. (2005b). Las TIC y las universidades: retos, posibilidades y preocupaciones. Revista de la Educación Superior, XXXIV (3), 135, 77-100.

Cabero, J., \& Barroso, J. (2016). La escuela en la sociedad de la información. La escuela 2.0. en "Nuevos escenarios digitales, Las tecnologías de la información y la comunicación aplicadas a la formación y desarrollo curricular", p. 32. Pirámide.

Chell, E., Haworth, J. M., \& Brearley, S. (1991). The entrepreneurial personality: Concepts, cases and categories. London: Routledge.

Colmenarez, S., Delgado, R. (2003). Reingeniería Socioeconómica y Desarrollo Endógeno Sostenible. Un programa macroeconómico alternativo para el desarrollo. Organización. Profuturo UNESCO. Caracas.

Dini, M (1996) Políticas Públicas para el Desarrollo de Redes de Empresas. La Experiencia Chilena, en Redes y Regiones: Una Nueva Configuración, Revista Latinoamericana de Estudios del Trabajo, Facultad Latinoamericana de Ciencias Sociales, México.

Drucker, P. (1985). Innovación y Emprendimiento. EEUU: HBR.

Evans, D., and Leigton, L. (1989). Some empirical aspects of entreprenership. Called in http://www.development.wne.uw.edu.pl/uploads/Courses/seme\%20empirical\%20aspects\%20of

Ferraro, V. (2008). Dependency theory: An introduction. In G. Secondi (Ed.), The development economic reader Pp. 58-64. London: Routledge.

Filion, L. J. (2011). 5 Defining the entrepreneur. World Encyclopedia of Entrepreneurship, 41.

Instituto Interamericano de Cooperación para la Agricultura (IICA), (2006). Gestión de Agronegocios en Empresas Asociativas Rurales.

Ireland, R. D., Reutzel, C. R., \& Webb, J. W. (2005). Entrepreneurship research in AMJ: what has been published, and what might the future hold?. Academy of Management Journal, 48(4), Pp. 556-564.

James, H. (2004). Citado por Heather's Blog (10.may.2004) en My Brilliant Failure: Wikis in Classrooms. [Mensaje de un blog]. Called from http://kairosnews.org/node/3794.

Kong, Y. (2009). A brief discussion on motivation and ways to motivate students in English Language Learning. International Education Studies Vol.2, No.2. p. 148

Knowles, S. (1970). The modern practice of adult education: Andragogy versus pedagogy. Book and Buzz.

Kates, R. W., Parris, T. M., \& Leiserowitz, A. A. (2008). What is sustainable development? Goals, indicators, values, and practice. In G. Secondi (Ed.), The development economics reader. Pp. 367-387. London: Routledge.

Lucas, R. E. (1988). On the mechanics of economic development. Journal of Monetary Economics, 22(1), 3-42

McClelland, D. C. (1965). N achievement and entrepreneurship: A longitudinal study. Journal of personality and 
Social Psychology, 1(4), p. 389.

Meier, G. M. (2000). The old generation of development economists and the new. In G. M. Meier \& J. E. Stiglitz (Eds.), Frontiers of development economics: The future in perspective. P.p. 13-50. Washington, D.C.: World Bank/Oxford University Press.

Michavila, F. \& Parejo, J. (2008). Políticas de participación estudiantil en el Proceso de Bolonia. Revista de Educación, número extraordinario 2008, Pp. 85-118.

Mideplan (2003). El Índice de Desarrollo Humano en la población mapuche de la región de La Araucanía, colección Temas de Desarrollo Humano Sustentable, núm. 8,Temuco: pnud/ufro-ider/mideplan

Ministerio De Coordinación De La Producción, Empleo Y Competitividad. (2011). Agenda para la Transformación Productiva Territorial. Quito: MCPEC.

Moon, B. (2014). Citado en "El desarrollo sostenible comienza por la educación". Publicado por la Organización de las Naciones Unidas para la Educación, la Ciencia y la Cultura. Francia.

Morán, J. (2010). Capital Social: Las redes sociales y su impacto sobre el desarrollo socioeconómico. Called from: www.eumed.ne Vlibros /2010f/860/

Porter, L. W., \& Smith, F. J. (1970). The etiology of organizational commitment. unpublished paper, University of California, Irvine, p. 970.

PUCESE. (2012). "Proyecto para la generación de Cultura emprendedora, a través de la aplicación de Cursos de Emprendimiento e Innovación en Colegios de la Provincia de Esmeraldas". Incubadora de Empresas. Esmeraldas, Ecuador.

Putnam, R. (1993). The Prosperous Community - Social Capital and Public Life, en American Prospect, n. 13. Washington. D.C

República del Ecuador. (2008). Constitución de la republica del Ecuador. Congreso de la república. Called from http://www.asambleanacional.gov.ec/documentos/constitucion_de_bolsillo.pdf

República del Ecuador. (2009). Plan nacional de desarrollo 2009-2013. SEMPLADES. Called from http://plan.senplades.gob.ec/web/guest/presentacion

Republica del Ecuador. (2010). Informe Nacional de estadísticas y Censos. Called from http://www. inec. gob. ec/estadisticas/

República del Ecuador. (2012). Law of Popular Economy and Solidarity Ley de Economía Popular y Solidaria. Quito. Called from http://www.oas.org/ juridico/PDFs/mesicic4_ecu_econ.pdf

República del Ecuador. (2012). National Budget period 2012. Quito. Called from http://www. inec. gob.ec/estadisticas/

Republica del Ecuador. (2013). National Plan of well living - Plan Nacional para el buen vivir 2013-2017. Called from http://www.buenvivir.gob.ec/

República del Ecuador. (2015). National Statistics INEC. Quito.

Called from http://www. inec. gob.ec/estadisticas/

Rosales, R. (1997). La asociatividad como estrategia de fortalecimiento de las PyMes. Universidad de Texas

Schiller, R., and Crewson, P. (1997). Entrepreneur origins: A longitudinal inquiry. Economic inquiry 35; Pp. 523531.

Skousen, M. (2007). The big three in economics: Adam Smith, Karl Marx and John Maynard Keynes. New York: ME Sharpe Inc.

Thampapillai, J. D. (2002). Environmental economics: Concepts, methods and policies. Australia: Oxford University Press.

Todaro, M., \& Smith, S. (2003). Economic development (8th ed.). Boston: Addison Wesley.

Todaro, M., \& Smith, S. (2009). Economic development (10th ed.). Boston: Addison Wesley.

United Nations. (2012). The millennium development goals report. New York.

Vanderwerf, P. A., \& Brush, C. G. (1989). Achieving empirical progress in an undefined field. Entrepreneurship Theory and Practice, 14(2), 45-58.

Valdez, L.R. (2007). Comunidades Productivas: asociatividad y Producción en el Territorio. Recuperado de: www.eumed.net/libros/2007a/268/

World Bank. (2003). Sustainable development in a dynamic world-Transforming institutions, growth, and quality of life (World Development Report). Washington, D.C.: World Bank/Oxford University Press. 